"From the corporate social responsibility reporting to the integrated reporting: the case of Sabaf S.p.a"

\begin{tabular}{|c|c|}
\hline AUTHORS & $\begin{array}{l}\text { Renato Camodeca } \\
\text { Alex Almici }\end{array}$ \\
\hline ARTICLE INFO & $\begin{array}{l}\text { Renato Camodeca and Alex Almici (2017). From the corporate social } \\
\text { responsibility reporting to the integrated reporting: the case of Sabaf S.p.a. } \\
\text { Problems and Perspectives in Management, 15(1-1), 150-157. } \\
\text { doi:10.21511/ppm.15(1-1).2017.01 }\end{array}$ \\
\hline DOI & http://dx.doi.org/10.21511/ppm.15(1-1).2017.01 \\
\hline RELEASED ON & Monday, 08 May 2017 \\
\hline RECEIVED ON & Monday, 26 September 2016 \\
\hline \multirow[t]{2}{*}{ ACCEPTED ON } & Wednesday, 08 February 2017 \\
\hline & $((c))$ EY-NO \\
\hline LICENSE & $\begin{array}{l}\text { This work is licensed under a Creative Commons Attribution-NonCommercial } 4.0 \\
\text { International License }\end{array}$ \\
\hline JOURNAL & "Problems and Perspectives in Management" \\
\hline ISSN PRINT & $1727-7051$ \\
\hline ISSN ONLINE & $1810-5467$ \\
\hline PUBLISHER & LLC "Consulting Publishing Company "Business Perspectives" \\
\hline FOUNDER & LLC "Consulting Publishing Company "Business Perspectives" \\
\hline
\end{tabular}

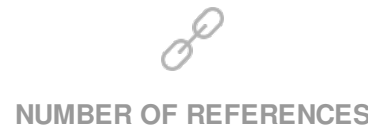

34
NUMBER OF FIGURES

0
NUMBER OF TABLES

4

(C) The author(s) 2023. This publication is an open access article. 


\title{
From the corporate social responsibility reporting to the integrated reporting: the case of Sabaf S.p.a
}

\begin{abstract}
In December 2013, the International Integrated Reporting Council (IIRC) published the International Integrated Reporting Framework.

The aim of the Framework is to provide the guiding principles and the content elements of an integrated report. The integrated report constitutes an evolutionary step in the corporate's financial and non-financial communication, moving from the social responsibility reporting to the integrated reporting.
\end{abstract}

This practice is at the beginning in Europe and especially in Italy, where only a few listed companies have decided to face the multitude of challenges the integrated report implies.

Considering the relevance of such a new form of communication, the paper examines the main steps carried out by an Italian listed company moving towards the integrated report. The research has been conducted by adopting a qualitative case study approach, by focusing on Sabaf S.p.a, an Italian listed medium sized company belonging to the Star Segment. This company has been selected, because it was one of the first adopters of the integrated report among the Italian listed companies.

The study is built on data gathered through sites visits, structured interviews and company materials.

The paper examines Sabaf's transition from the corporate social responsibility report to the integrated report, aiming at answering the following research question:

Why has Sabaf moved to integrated reporting? Which are Sabaf's main steps towars the integrated report? How is the Sabaf's integrated reporting process going?

The findings should be of interest to a number of parties including standard setters, firms, financial advisors, auditors and users of non-financial statements.

Keywords: integrated reporting, sustainability, corporate social responsibility.

JEL Classification: M14, Q56, M40, M41.

Received on: $26^{\text {th }}$ of September, 2016.

Accepted on: $8^{\text {th }}$ of February, 2017.

\section{Introduction}

In December 2013, the International Integrated Reporting Council (IIRC) published the International Integrated Reporting Framework (hereafter "Framework"), along with two other documents named "Basis for Conclusions" and "Summary of Significant Issues", with the aim of providing the guidelines that govern the overall content of an integrated report.

This communication tool is still an uncommon practice, especially in Italy. In fact, despite a growing demand for transparency, very few Italian companies are currently issuing an integrated report. Even literature has only recently and partially dealt with the issues of integrated reporting focusing on the analysis of Framework, but without giving great attention to the transition experienced by the Italian companies through the implementation of the integrated reporting.

(c) Renato Camodeca, Alex Almici, 2017.

Renato Camodeca, Associate Professor, Department of Economics and Management, University of Brescia, Certified Public Accountant, Brescia, Italy.

Alex Almici, Ph.D. in Business Administration, Department of Economics and Management, University of Brescia, Certified Public Accountant, Brescia, Italy.

This is an Open Access article, distributed under the terms of the Creative Commons Attribution-NonCommercial 4.0 International license, which permits re-use, distribution, and reproduction, provided the materials aren't used for commercial purposes and the original work is properly cited.
The purpose of this paper is to examine the reasons and the main steps of Sabaf's transition towards the integrated reporting in terms of improvement of company's communication approach. In fact, the integrated report constitutes an evolutionary step with respect to social and sustainability reports. Integrated reporting seeks to offer a more holistic picture of the modern corporation by moving from standalone sustainability or social responsibility reports towards an integrated report that could be able to communicate, as a whole, the value creation process of the company. Indeed, integrated reporting includes non-financial information on environmental and social metrics, but goes much further to integrate these metrics with the traditional financial report.

Based on the above and in view of the Italian listed companies scenario, we focused on a specific company that stands out in Italy for having adopted the integrated disclosure process much earlier than most other domestic and international companies.

The analysis carried out concerns Sabaf S.p.a. (hereafter "Sabaf"), a large ${ }^{1}$ listed Italian company

\footnotetext{
${ }^{1}$ According to the European Union Directive 2013/14, large companies are those which exceed the limits of at least two of the three following criteria on the balance sheet date:

- balance sheet total: $€ 20,000,000$;

- net turnover: $€ 40,000,000$;
} 
belonging to the Star Segment ${ }^{2}$, one of the world's leading manufacturers of components for household gas appliances. The other Italian listed companies that publish an integrated report moved to this process later than Sabaf (Eni starting from 2010; Atlantia in 2012; Generali and Terna in 2013; Unicredit starting from 2014).

This paper uses the case study methodology and aims to answer the following research questions: Why is Sabaf moving to integrated reporting? Which are Sabaf's main steps towards the integrated report? How is the Sabaf's integrated reporting process going?

In order to answer the above questions, sites visits and interviews were carried out, while company material was analyzed.

This paper is structured as follows.

Section1 provides a brief description of Sabaf, including a short history of the evolution from a family-owned company to a listed one.

Section 2 shows a literature review about integrated reporting, focusing on the key contributions with regard to the Framework issues.

Section 3 describes the research approach.

Section 4 deals with the case study in terms of the route taken by Sabaf towards the integrated report and features of this document with respect to the Framework; the last one contains some concluding remarks, trying to answer the abovementioned questions.

\section{The company}

Sabaf was founded in Lumezzane (Brescia, Nothern Italy) in the 1950 s by the Saleri family; while Sabaf began as a family firm and has remained so, management has been progressively assigned to professionals outside the Saleri family.

Sabaf started its activity by producing brass taps, initially for the farming sector. Only at the beginning of the 1960s Sabaf focused on the production of taps for gas cooking.

At the end of the 1960s, Sabaf started the production of gas thermostats, while in the early 1980s, Sabaf began the production of a special gas burner. This innovation marked a revolution in the whole market of global domestic appliances, because it allowed the

- average number of employees during the financial year: 250 .

${ }^{2}$ Star is the market segment of the Italian Stock Exchange's equity market (MTA) dedicated to midsize companies with a capitalization of less than 1 billion euros and who voluntarily adhere to and comply with the following strict requirements:

- high transparency and high disclosure requirements;

- high liquidity (minimum $35 \%$ of free float);

- corporate governance in line with international standards.

Italian and foreign institutional investors, as well as private investors appreciate the high quality of the STAR segment. The companied listed on STAR are leaders in their industry. significant reduction of the depth of cooking appliances and, therefore, the diffusion of built-in hobs.

At the end of the 1990s, Giuseppe Saleri, one of the main shareholders, acquired Sabaf shares from his brothers and started out on a path that would take the company to its present-day levels, first, moving from a family-run business to a professional management one, then, to a listing on the Milan Stock Exchange (in 1998) and the inclusion in 2001 of the Sabaf shares in the so-called 'High Performance Equities Segment' (Star Segment). The listing marked the formal separation between ownership and management, who were external to the Saleri family.

Starting from the 2000s, Sabaf began to increase its dimensions both by external and internal means.

In 2000s, with the intention of enlarging its product portfolio and entering into related sectors, Sabaf acquired Faringosi Hinges, a small company dealing in the production of hinges for oven and dishwasher doors. In 2001, Sabaf started the globalization of its business; in this year, with the intention of better serving Sabaf customers in South America, it has founded Sabaf do Brasil.

The globalization of Sabaf's business continued in 2012 by producing burners in Turkey. In 2015, Sabaf expanded its activities in China through a new production plant located in Kunshan (China), aimed at producing burners for the Chinese market.

In 2000, Sabaf decided to address the issues of sustainable development and corporate social responsibility. Consequently, the Project Group for Corporate Social Responsibility was established and it published the first edition of the Social Responsibility Report, which, then, continued until the creation of the integrated report some time later (note Section 4 for the analysis of Sabaf's route towards the integrated report).

\section{A literature review on integrated reporting}

Despite the fact that the integrated report issue has progressively gained prominence in the academic and professional world over the last decade and among international standard setters, literature on the subject has only partially addressed it, focusing only on some specific profiles. For example, we see the almost total lack of studies to analyze the value relevance of the integrated report; furthermore, there is a shortage of empirical research aimed at assessing the actual degree to which the integrated report has been adopted by companies.

Eccles (2010, 2011, 2012, 2014), Jensen and Berg (2012) are among those who first addressed the issue of the integrated report.

As part of Eccles' contributions, the adoption of the integrated report is strongly promoted in so far as it can produce many internal and external benefits. It 
can produce internal benefits, which are identifiable in reducing risks linked to reputation, the increased involvement of shareholders and all stakeholders in general and in taking appropriate decisions to ensure a better use of internal resources. It can also produce external benefits, referring to market advantages arising not just from economic disclosure; regulatory, in terms of greater capability to respond to the increasing local stock exchanges requirements (Eccles et al., 2010, 2011, 2012, 2014).

With reference to the institutionalist theory, Jensen and Berg (2012) also emphasize the added value of the integrated report compared to other forms of communication; to that end, aspects of commonality and differentiation are studied between companies that prepare an integrated report and those who resort to a sustainability report (Jensen and Berg, 2012).

From 2013, we notice some contributions of a highly critical nature, especially with regard to the integrated report model proposed by the IIRC (Brown and Dillard, 2014; Flower, 2015; Thomson, 2015).

Brown and Dillard consider IIRC's approach to the integrated report to be particularly limited and unsuitable in stimulating more responsible behavior; the authors also urge greater attention to the social, political and economic context in drafting the integrated report (Brown and Dillard, 2014).

Compared to the version provided by the Consultation Draft, Flower believes that the definitive Framework version has abandoned sustainability accounting, identifying the main reason in the composition of the IIRC governing bodies, mainly in respect of the accounting professions and representatives of multinational enterprises. Flower also challenges the scarcely binding nature of the provisions contained in the Framework on consequent potential problems in terms of effectiveness (Flower, 2015).

Similarly, taking up Flower's study, Thomson criticizes the IIRC's Framework, identifying its main weakness in the absence of adequate appreciation of the sustainability principle (Thomson, 2015).

Other studies have corroborated the importance of the integrated report, highlighting the potential and possible benefits (Adams, 2015; Burke and Clark, 2016; Stacchezzini, Melloni and Lai, 2016). Adams highlights, in particular, the limitations of Flower's criticism, replicating that the alleged departure from sustainability does not constitute a source of weakness, given that the representation of corporate sustainability is not the integrated report's main objective (Adams, 2015). Even Stacchezzini et al. analyze the integrated report role, especially in communicating corporate sustainability practices; in this regard, their research's findings underline how firms not only provide limited forward-looking and quantita- tive disclosure of their actions to achieve sustainability outcomes, but also avoid providing information about their sustainability performance when their social and environmental results are poor (Stacchezzini et al., 2016).

Some analyses have been made to verify whether the integrated report can actually encourage the adoption of more responsible behavior; in this regard, based on interviews with representatives of fifteen Australian businesses, Stubbs and Higgins have questioned whether internal mechanisms developed through the integrated reporting process are likely to impact on corporate culture, stimulating greater attention to sustainability and the consequent adoption of innovative forms of disclosure (Stubbs and Higgins, 2014).

According to an institutionalist approach, Higgins et al. analyze the possible readings of the information contained in the integrated report; the authors point out that the approaches to reading are often conflicting, thus, limiting the role of the integrated report with respect to the assertion of more responsible management behavior (Higgins, Stubbs and Love, 2014).

With regard to the South Africa case, Rensburg and Botha have proved the importance the integrated report has taken on for stakeholders to acquire preliminary information upon making an investment. The research shows how the integrated report is just an additional information source with respect to the traditional economic and financial ones, which, however, amounts to the primary reference for the investing public (Rensburg and Botha, 2014).

As part of the literature on integrated reporting, it is also possible to identify the studies focused on the analysis of theories (in particular, stakeholder theory, institutional theory and innovation diffusion theory) to which the integrated reporting process relates (Ioana and Adriana, 2014), or the theoretical and practical challenges of the problems arising from a non-unique application and interpretation of the integrated report (De Villiers, Rinaldi, Unerman, 2014).

However, there are only a few studies aiming at providing insights into the early stage development of the integrated reporting process; one of the first surveys conducted in this regard was the one by Wild and Van Staden on integrated reports - published between 2010-2012 - of the fifty-eight companies included in the IIRC's Integrated Reporting Emerging Practice Examples Database (Wild and Van Staden, 2013). This study found that early integrated reports were in general lengthy rather than concise, but failed to adhere to all the guiding principles.

The surveys conducted by Lai et al. (Lai, Melloni and Stacchezzini, 2013), Incollingo (Incollingo, 2014) and Salvioni et al. (Salvioni and Bosetti, 2014) refer to this context, as well as the above 
stated one; the first one aims at checking the business model disclosure practices in the integrated reports of twenty-one European companies. The second and the third ones verify the integrated reports' compliance to the Framework by the members of the Pilot Program.

\section{Research approach}

In this paper, we adopted a "descriptive" case study approach (Ryan et al., 1992).

Having a widespread application for teaching purposes, case studies can also be seen as a guide to establishing a frame for data collection in a particular piece of research, thereby seeking to cover contextual conditions, which might be relevant for the phenomenon being studied (Herzig et al., 2012). Case studies are particularly suitable for research areas where there are a few prior theroretical pieces of literature or empirical research work (Eisenhardt, 1989) and the most appropriate research question are those asking "how" and "why" (Yin, 2003) rather than those requiring broad statistical analysis.

According to the case study approach, we proceeded as follows.

Firstly, we carried out a content analysis - using qualitative coding techniques (Strauss and Corbin, 1990, 1998) - based on the study of the Sabaf's Annual Reports available on the company web site (especially the 2000-2004 corporate social responsibility reports and the integrated reports from 2005 to 2015). We also compared the Sabaf's corporate social responsibility and integrated reports with the integrated report preparation documents edited by the IIRC (IIRC, 2011, 2013). Secondly, the information gathered through the content analysis has been related to the information acquired as a result of a structured interview with $\mathrm{Sa}$ baf's CFO and Investor Manager.

Interview data have been analyzed in searching for an explanation of at least three issues: the reason for Sabaf's moving to the integrated reporting; the main steps of this transition; the current state of progress.

In detail, in order to answer the above stated question, the questionnaire's structure and the analysis of company's documents were aimed at investigating the following main aspects:

- the way and the reasons of Sabaf's route towards the integrated report;

- the main recommendations Sabaf has complied with in the preparation of its integrated report;

- Sabaf's compliance with the Framework's guiding principles;

- Sabaf's compliance with the Framework's content elements;

- the interactions between the Sabaf's integrated report and the other Sabaf's reports.
On this basis, the next subsections present:

- firstly, the main steps of Sabaf's path towards the integrated report;

- secondly, the way the Framework guidelines (guiding principles and content elements) are reflected in Sabaf integrated report.

\section{The integrated report at Sabaf}

4.1. Sabaf's route towards the integrated report. 4.1.1. The listing and corporate social responsibility reporting (1998-2004). Sabaf's listing on the Milan Stock Exchange led the company towards the progressive awareness of the opportunity to communicate transparently with all company stakeholders. In particular, during the period immediately following Sabaf's listing, there was an increase in the company's awareness of the issue of social responsibility and the related involvement of different social partners (customers, suppliers, employees, lenders, government, local communities, etc.).

For Sabaf, the choice to communicate their performance in both economic and non-economic aspects reflects a deep belief about implementing decisions based on the principles of sustainability and social responsibility.

This awareness brought Sabaf to draft their first corporate social responsibility report in 2000 . The choice to develop a different form of communication - in addition to the traditional economic one pointed to the concrete implementation of an external cultural incentive (represented, as mentioned above, by a growing attention to the issue of corporate social responsibility), as well as to the desire to build a long-term relationship with stakeholders.

In the Sabaf's view, starting out on the preparation of the corporate social responsibility report was not a tool for gaining reputational or image benefits, but the expression of their authentic will to adhere to new communication codes.

Drawing up the corporate social responsibility report was, for Sabaf, the formal undertaking of a process towards an alternative form of communication - no longer just economic and mainly aimed at the shareholders - but broader in scope, based on shared values with all stakeholders.

4.1.2. The integration between economic and noneconomic information (2005-2009). Sabaf used to publish the corporate social responsibility report separately and at a later stage than the annual report.

The need to be able to provide reference representatives (especially financial analysts and banks) with the corporate social responsibility report, together with the consolidated financial statements, induced Sabaf to decide to merge - as of 2005-- financial and non-financial reporting in a single document entitled "Integrated Annual Report". 
In the Sabaf's view, moving to an integrated annual report expressed the transition from a localized approach of corporate disclosure to a holistic type of vision, although we cannot speak of an integrated report as envisaged by the Framework at this step of the Sabaf's route towards the integrated reporting. The "Integrated Annual Report" of 2005 constitutes, in fact, a mere aggregation of financial and non-financial information, without underlying variables such as risk management, corporate strategy and the choice of governance.

The integrated report was published according to the approach described above until around 2010, the year the International Integrated Reporting Council (IIRC) was established.

Since 2011, Sabaf has undertaken a process of further improvement of their reporting by acknowledging the first recommendations of the IIRC on integrated communication (IIRC, 2011).

4.1.3. The integrated report according to the Framework (2011-2015). Only after the establishment of the IIRC in August 2010 and the publication of a series of documents regarding the integrated report (especially, IIRC 2011), Sabaf undertook the review of their annual report according to an integrated approach in which sustainability and value creation are linked - according to a long-term approach - to the system of risk management and governance, the business strategy, the impact on the allocation of available resources and the ability to provide reliable projections of future performance.

Since December 2013, with the publication of the Framework, Sabaf was also provided with a formal set of rules and guidelines applicable to the preparation of the integrated report.

However, Sabaf implemented the Framework's guidelines by emphasizing sustainability, social corporate responsibility and all stakeholders' safeguard principles. In this regard, Sabaf's integrated report does not reflect the literature's criticism about the Framework's negligence with regard to sustainability issue. In fact, Sabaf prepared its integrated report focusing on sustainability and social corporate responsibility, rather than on the value for investors as required by the Framework.

The analysis of Sabaf implementation's process of the Framework guidelines is provided in the next subsection.

4.2. The Framework and Sabaf's integrated report. This subsection is about the analysis of 2015 Sabaf's integrated report, with respect to the provisions of the Framework.

In preparing its integrated report, Sabaf has complied overall with both the recommendations contained in the Global Reporting Initiative standards
(GRI) regarding sustainability and those provided under the Framework, although, with regard to the latter, with some specific characterizations indicated as follows.

For the purpose of preparing an integrated report, the Framework identifies specific guiding principles in addition to defining core themes to be developed. In particular, the guiding principles consist of general rules to be followed when processing the document in question, namely (Table 1):

Table 1. The Framework guiding principles

\begin{tabular}{|l|l|}
\hline Strategic focus & $\begin{array}{l}\text { Insight into the organization's strategy and how } \\
\text { it relates to the company's ability to create and } \\
\text { sustain value over time. }\end{array}$ \\
\hline Future orientation & Management's expectations about the future. \\
\hline $\begin{array}{l}\text { Connectivity of informa- } \\
\text { tion }\end{array}$ & $\begin{array}{l}\text { Connections among the factors that affect the } \\
\text { company's ability to create value over time. }\end{array}$ \\
\hline ships & $\begin{array}{l}\text { Company's relationships with its key stake- } \\
\text { holders, including how and what extent the } \\
\text { organization understands, takes into account } \\
\text { and responds to their legitimate needs and } \\
\text { interests. }\end{array}$ \\
\hline Materiality & $\begin{array}{l}\text { Focus on matters that substantively affect the } \\
\text { company's ability to create value over time. }\end{array}$ \\
\hline Conciseness & Disclosing in a concise manner. \\
\hline $\begin{array}{l}\text { Reliability and com- } \\
\text { pleteness }\end{array}$ & $\begin{array}{l}\text { Disclosing reliable information, including all } \\
\text { material matters, both positive and negative. }\end{array}$ \\
\hline Consistency & $\begin{array}{l}\text { Disclosing on a basis that is consistent over } \\
\text { time. }\end{array}$ \\
\hline Comparability & Enabling comparison with other companies. \\
\hline
\end{tabular}

With respect to the Framework's guiding principles, Sabaf's 2015 integrated report gives special prominence to the principle of materiality, which should be an indication to present only the information that may significantly affect the company's ability to create value. In detail, among the so-called material (or relevant) subject areas, Sabaf identifies the following:

- staff training;

- industrial relations;

- remuneration and incentives policies;

- atmospheric emissions;

- waste management and environmental impact;

- research and innovation;

- partnerships with multinational groups, getting established in international markets and customizing products for emerging market;

- the distinctive image of the Group;

- customer satisfaction;

- eco-efficiency and product quality management;

- managing relationships with suppliers;

- health and safety of personnel;

- staff recruitment policies;

- internal communications;

- diversity and equal opportunity;

- protection of human rights;

- performance evaluation and career development.

With reference to the content elements, the Framework identifies the following items (Table 2): 
Table 2. The Framework's content elements

\begin{tabular}{|l|l|}
\hline $\begin{array}{l}\text { Organizational overview and the } \\
\text { external environment }\end{array}$ & What does the organization do \\
\hline Governance & $\begin{array}{l}\text { What is the organization's governance } \\
\text { structure, and how does governance } \\
\text { support the strategic objectives of the } \\
\text { organization? }\end{array}$ \\
\hline Business model & $\begin{array}{l}\text { How does the organization create and } \\
\text { sustain value in the short, medium and } \\
\text { long term? }\end{array}$ \\
\hline Risks and opportunities & $\begin{array}{l}\text { What are the circumstances under which } \\
\text { the organization operates, including the } \\
\text { key risks and opportunities that it faces? }\end{array}$ \\
\hline $\begin{array}{l}\text { Strategy and allocation of re- } \\
\text { sources }\end{array}$ & $\begin{array}{l}\text { Where does the organization want to go } \\
\text { and how does it intend do get there? }\end{array}$ \\
\hline Performance & $\begin{array}{l}\text { How has the organization performed } \\
\text { according its strategic objective? }\end{array}$ \\
\hline Outlook & $\begin{array}{l}\text { What opportunities, challenges and } \\
\text { uncertainties is the organization likely to } \\
\text { encounter? }\end{array}$ \\
\hline Basis of preparation and presen- \\
tation & $\begin{array}{l}\text { How does the organization determine } \\
\text { what matters to include in the inte- } \\
\text { grated report and how are such matters } \\
\text { quantified or evaluated? }\end{array}$ \\
\hline
\end{tabular}

With regard to the content, Sabaf's integrated report places particular emphasis on corporate strategy, future orientations, the risk management system, seizing opportunities and governance choices.

The evidence of such content enables Sabaf to show how the company creates value according to sustainability conditions. With reference to content elements, Sabaf partially distances itself from the Framework's founding approach, wholly inspired by the need to illustrate how the company creates value by targeting, in particular, the investors. In this regard, Sabaf does not implement the guidelines provided by the Framework in an uncritical manner, as it focuses the attention on the achievement of sustainable conditions, taken to be the reconciliation of all of the company's stakeholders' expectations (economic, social and environmental). Therefore, Sabaf does not identify the shareholders and the lenders as the privileged recipients of the integrated report - as assumed in the Framework - but all stakeholders potentially interested in learning about corporate performance not only in the short but also especially in the medium and long term.

In particular, the contents of the 2015 integrated report provide the breakdown shown in Table 3.

Table 3. The Sabaf's 2015 integrated report: the main thematic areas

\begin{tabular}{|c|}
\hline Business model and strategic approach \\
\hline International dimension and markets \\
\hline Corporate governance, risk management, compliance and remuneration \\
\hline Social and environmental sustainability \\
\hline Management report \\
\hline Consolidated financial statement as of 31 December 2015 \\
\hline Separate financial statement as of 31 December 2015 \\
\hline Remuneration report \\
\hline
\end{tabular}

Below, we show how Sabaf presented their business model, risk management system and social and environmental sustainability in the 2015 integrated report; it is, above all, the illustration of these areas that - together with the traditional economic disclosure - should be representative of a company's value creation process.

\section{Business model and strategic approach}

The business model's presentation comes about, as required by the Framework, by identifying inputs that is the capital, which a company has available to run its business - and related outputs, as well as the significant areas to which the company's strategy refers. The latter comprise innovation, ecoefficiency, safety, establishment in international markets, increase in the range of components and international partnerships and the appreciation of intellectual capital. Sabaf considers the focus on these issues to be a necessary step in order to create value under sustainable conditions. In particular, to allow the principles of sustainable development to be integrated with corporate management choices, Sabaf leverages six main factors, namely: training and communication, the sharing of values, sustainability mission and strategy, the presence of an effective internal control system, the selection of specific key performance indicators that can monitor the economic, social and environmental performance, the development of a clear and comprehensive reporting system that can effectively inform the various stakeholder categories and the promotion of a stakeholder engagement approach.

\section{Risk management}

Sabaf has developed a risk management system focused on the identification, assessment and management of the main corporate risks, estimating their impact and likelihood of occurrence, as well as of the measures taken to manage them. The main risks identified by Sabaf included: the instability of the emerging countries, where Sabaf is present, potential resistance to change by the organization, the difficulties arising from the internationalization process, credit management, the loss of and/or difficulty in finding resources and core skills, the fluctuation in exchange rates and the volatility of commodity prices. Sabaf's attention to risk management shows a further tendency factor in creating value. In fact, the effort to monitor potential threats is directly related to the opportunity of safeguarding company's performance.

\section{Social and environmental sustainability}

The 2015 integrated report chapter dedicated to social and environmental sustainability is an expression of Sabaf's desire to lend weight to these aspects, regardless of the Framework's requirements, focused instead on the creation of investor orien- 
tated value. In other words, Sabaf focuses attention on the expectations of all company stakeholders (employees, customers, suppliers, shareholders, public administration, financiers and competitors), illustrating the contribution and impact the business has on the social and environmental dimension. In detail, Sabaf emphasizes the relations with the company's staff by calculating specific indicators regarding: the staff turnover; the total hours of training provided; the incentive and promotion systems; the employment policy; the working hours and the hours of absence; the occupational health and safety; the participation in trade unions activities; the company's climate. This approach expresses the Sabaf's need to fulfil all stakeholders' expectations; from this point of view, an effective integrated report should disclose all the company's information, both financial and non-financial one.

\subsection{The literature, the Framework and Sabaf's} integrated report. With reference to the literature mentioned in Section 2, we examined to what extent Sabaf's integrated report relates to the main issues raised by different authors on the Framework (Table 4).

Table 4. Sabaf's integrated report with respect to the main criticism of the Framework

\begin{tabular}{|c|c|c|c|}
\hline Authors & Year & IR weakness & Sabaf's integrated report \\
\hline $\begin{array}{l}\text { Brown } \\
\text { and Dil- } \\
\text { lard }\end{array}$ & 2014 & $\begin{array}{l}\text { Unsuitable in stimulat- } \\
\text { ing more responsible } \\
\text { behavior; little attention } \\
\text { to the social, political } \\
\text { and economic context. }\end{array}$ & $\begin{array}{l}\text { Sabaf believes that the } \\
\text { integrated report has en- } \\
\text { couraged the adoption of } \\
\text { more responsible behavior } \\
\text { over time. }\end{array}$ \\
\hline $\begin{array}{l}\text { Higgins, } \\
\text { Stubbs } \\
\text { and Love }\end{array}$ & 2014 & $\begin{array}{l}\text { The approaches to } \\
\text { reading are often } \\
\text { conflicting, thus limiting } \\
\text { the role of the inte- } \\
\text { grated report with } \\
\text { respect to the asser- } \\
\text { tion of more responsi- } \\
\text { ble management } \\
\text { behavior. }\end{array}$ & $\begin{array}{l}\text { According to Sabaf, the } \\
\text { integrated report consti- } \\
\text { tutes a useful tool for } \\
\text { learning more thoroughly } \\
\text { about the reality of the } \\
\text { business. However, the } \\
\text { reading of the document in } \\
\text { question can vary depend- } \\
\text { ing on how evolved the } \\
\text { third party readers are. }\end{array}$ \\
\hline $\begin{array}{l}\text { Rensburg } \\
\text { and Botha }\end{array}$ & 2014 & $\begin{array}{l}\text { Secondary value of the } \\
\text { integrated disclosure } \\
\text { with respect to tradi- } \\
\text { tional economical and } \\
\text { financial communica- } \\
\text { tions. }\end{array}$ & $\begin{array}{l}\text { For Sabaf, the integrated } \\
\text { report is intended as a } \\
\text { single document in which } \\
\text { to bring together both the } \\
\text { financial and non-financial } \\
\text { information. }\end{array}$ \\
\hline Flower & 2015 & $\begin{array}{l}\text { Little attention to the } \\
\text { issue of sustainability. } \\
\text { The content of the } \\
\text { Framework's require- } \\
\text { ments is poorly bind- } \\
\text { ing. }\end{array}$ & $\begin{array}{l}\text { Sabaf gives prominence to } \\
\text { the issue of sustainability. }\end{array}$ \\
\hline Thomson & 2015 & $\begin{array}{l}\text { A lack of adequate } \\
\text { appreciation of the } \\
\text { sustainability aspect. }\end{array}$ & $\begin{array}{l}\text { Sabaf gives prominence to } \\
\text { the issue of sustainability. }\end{array}$ \\
\hline
\end{tabular}

\section{References}

1. Abbott, W. and Monsen, R. (1979). On the measurement of corporate social responsibility: self-reported disclosure as a measure of corporate social involvement, Academy of Management Journal, Vol. 22, 501-515.

2. Adams, C. A. (2015). The International Integrated Reporting Council: A call to action. Critical Perspetctives on Accounting, No. 27, 23-28.

3. Brown, J., and Dillard, J. (2014). Integrated reporting: on the need for broadening out and opening up, Accounting, Auditing and Accountability Journal, Vol. 27, No. 7, 1120-1156. 
4. Burke, J. J. and Clark, C.E. (2016). The business case of integrated reporting: insights from leading pratictioners, regulators and academics, Business Horizons, 1-11.

5. De Villiers, C., Rinaldi, L. and Unerman, J. (2014). Integrated Reporting: Insights, gaps and an agenda for future research, Accounting, Auditing and Accountability Journal, Vol. 27, No. 7, 1042-1067.

6. Eccles, R.G. and Krzus, M. P. (2010), One report - Integrated Reporting for a Sustainable Strategy, New York, Wiley \& Sons.

7. Eccles, R. G., Beiting, C. and Saltzman, D. (2010). "The Landscape of Integrated Reporting”, Harvard Business School, Boston.

8. Eccles, R. G. and Saltzman, D. (2011). Achieving sustainability trough integrating reporting, Stanford Social Innovation Review, 57-61.

9. Eccles, R.G., Krzus, M.P. and Watson, L.A. (2012). Integrated reporting requires Integrated Assurance, in Oringel, J., Effective Auditing for Corporates: Key Developments in Practice and Procedures, London, Bloomsbury Information.

10. Eccles, R.G. and Krzus, M. P. (2014). Integrated Reporting Movement. Meaning. Momentum. Motives and Materiality, New York, Wiley.

11. Eisenhardt, K. M. (1989). Building theorie from case study research, Academy of Management Review, 14, 532-550.

12. Flower, J. (2015). The International Integrated Reporting Council: A story of failure, Critical Perspectives in Accounting, Vol. 17, 1-17.

13. Higgins, C., Stubbs, W. and Love, T. (2014). Walking the talk(s): Organisational narratives of integrated reporting, Accounting, Auditing and Accountability Journal, Vol. 27, No. 7, 1090-1119.

14. Jensen, J.C. and Berg, N. (2012). Determinants of Traditional Sustainability Reporting Versus Integrated Reporting. An Institutionalist Approach, Business Strategy and the Environment, n. 21.

15. Herzig, C., Viere, T., Schaltegger, S. and Burritt, R. (2012), Environmental management accounting. Case studies of South-East Asian companies, Routledge.

16. Incollingo, A. (2014). Le prime esperienze di bilancio integrato, Giappichelli, Torino.

17. International Integrated Reporting Council, (2011). Towards Integrated Reporting - Communicating Value in the 21st Century, Discussion Paper. Retrieved from http://www.theiirc.org.

18. International Integrated Reporting Council. (2013). The International IR Framework, Retrieved from http://www.theiirc.org.

19. International Integrated Reporting Council. (2013). Summary of significant issues, Retrieved from http://www.theiirc.org.

20. International Integrated Reporting Council. (2013). Basis for conclusions, available at: http://www.theiirc.org.

21. International Integrated Reporting Council, (2013). Value Creation. Background Paper for IR. Retrieved from http://www.theiirc.org.

22. Ioana, D., and Adriana, T.-T. (2014). Research agenda on integrating reporting: new emergent theoy and practice, Procedia Economics and Finance, Vol. 15, 221-227.

23. Krippendorff, K. (1980). Content Analysis: An Introduction to its Methodology, London, Sage.

24. Lai, A., Melloni, G. and Stacchezzini, R. (2013). Disclosing Business Model in the "Integrated Report": Evidence from European Early Adopters, Paper presentato al Convegno Bicentenario Aidea, Lecce, 19-21 settembre 2013.

25. Rensburg, R. and Botha, E. (2014). Is integrated reporting the silver bullet of financial communication? A stakeholder perspective from South Africa. Public Relations Review, No. 40, 44-152.

26. Ryan, B., Scapens R. and Theobal M. (1992). Research Method and Methodology in Finance and Accounting, Academic Press, London.

27. Salvioni, D. and Bosetti, L. (2014). Stakeholder engagement and integrated reporting: evidence from the adoption of the IIRC Framework. Paper presented at International Multidisciplinary Academic Conference, Institute of Strategic and International Studies, Paris.

28. Stacchezzini, R., Melloni, G. and Lai, A. (2016). Sustainability management and reporting: the role of integrated reporting for communicating corporate sustainability management, Journal of Cleaner Production, 1-9, http://dx.doi.org/10.106/j.jclepro.2016.01.109.

29. Strauss, A. and Corbin, J. (1990/1998). Basics of Qualitative Research: Techniques and Procedures for Developing Grounded Theory, 2nd ed., Sage Publications, Thousand Oaks, CA.

30. Stubbs, W. and Higgins, C. (2014). Integrated Reporting and internal mechanism of change, Accounting, Auditing \& Accountability Journal, Vol. 27, No. 7, 1068-1089.

31. Thomson, I. (2015). But does sustainability need capitalism or an integrated report - a commentary on «The International Integrated Reporting Council: A story of failure» by Flower, J., Critical Perspectives on Accounting, No. 27, 18-22.

32. Weber, R. (1990). Basic Content Analysis, 2nd Ed., Sage University Paper Series on Quantitative Applications in the Social Sciences No 49, Newbury Park, Sage.

33. Wild, S. and Van Staden, C. (2013). Integrated Reporting: Initial analysis of early reporters - an Institutional Theory approach, paper presentato al $7^{\text {th }}$ Asia Pacific Interdisciplinary Research in Accounting Conference, Kobe, Japan.

34. Yin, R. K. (2003). Case study research, Thousand Oaks, Sage. 